\title{
Morphological aspects of fruits, seeds and seedlings of Rhamnidium elaeocarpum Reissek
}

\section{Aspectos morfológicos de frutos, sementes e plântulas de Rhamnidium elaeocarpum Reissek}

\author{
Lílian Abadia da Silva ${ }^{1 *}$; Juliana de Fátima Sales²; Renato Mendes Guimarães ${ }^{3}$; \\ João Almir Oliveira4; Sebastião Carvalho Vasconcelos Filho²
}

\begin{abstract}
Rhamnidium elaeocarpum Reissek is a species found in forests, especially in riparian forests. This medicinal species is commonly used to reduce itching of the gums in children at the onset of teething and contains several substances responsible for antiulcer activity. The aim of the present study was to describe the external and anatomical features of the seeds, fruits, and developmental stages of seedlings of $R$. elaeocarpum Reissek. The processing consisted of maceration in sieves to separate the seeds from the waste. To describe the fruit, external details of the pericarp were observed and for the seeds, the external structures of the integument and internal structures of the endosperm and embryonic axis were analyzed. The morphological aspects of the seeds, germination, and seedlings of Rhamnidium elaeocarpum Reissek are homogenous in all phases. The fruit is simple, fleshy, indehiscent, and berry monospermic. The seed is exalbuminous and cream colored, with a thin and rough integument, the presence of tannin content, and an endosperm rich in starch, calcium oxalate crystals, and lipid content. Germination is hypogeal, and the seedling is cryptocotyledonary
\end{abstract}

Key words: Morphological aspects, germination, post-seminal development, Rhamnaceae

\section{Resumo}

O Rhamnidium elaeocarpum Reissek é uma espécie encontrada em formações florestais, especialmente em matas ciliares, sendo uma planta medicinal com properiedades antiúlcerativas e utilizada para reduzir o prurido das gengivas de crianças no início da dentição e. No presente trabalho, objetivouse a descrição morfo-anatômica do fruto, da semente e das plântulas de $R$. elaeocarpum Reissek. $\mathrm{O}$ beneficiamento consistiu da maceração dos frutos em peneira, separando as sementes dos resíduos. Para a descrição dos frutos foram observados detalhes externos do pericarpo e para as sementes foram analisadas as estruturas externas do tegumento e internas do endosperma e do eixo embrionário. Os aspectos morfológicos das sementes, germinação, e plântulas de Rhamnidium elaeocarpum Reissek são homogêneas em todas as fases. $\mathrm{O}$ fruto é simples, carnudo, indeiscente, do tipo baga monospérmica. A semente é exalbuminosa de coloração creme, com tegumento fino. No endosperma foi detectada a presença de taninos, grânulos de amido, cristais de oxalato de cálcio, e lípidos. A germinação é hipógea criptocotiledonar.

Palavras-chave: Morfologia, germinação, desenvolvimento pós-seminal, Rhamnaceae

1 Bióloga, Discente do Curso de Doutorado do Programa de Pós-Graduação em Ciências Agrárias. Instituto Federal de Educação, IFE, Ciência e Tecnologia Goiano, Rio Verde, GO, Brasil.E-mail: lilianabadia5@gmail.com

2 Biólogos, Profs. Drs., IFE, Ciência e Tecnologia Goiano, Rio Verde, GO, Brasil. E-mail: juliana.sales@ifgoiano.edu.br; sebastiaovasconcelos@hotmail.com

3 Biólogo, Prof. Dr., Dept ${ }^{\mathrm{o}}$ de Agricultura, Universidade Federal de Lavras, UFLA, Setor de Sementes, Lavras, MG, Brasil. E-mail: renatomg@dag.ufla.br

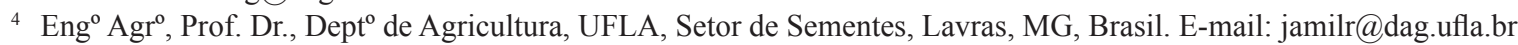

* Author for correspondence 


\section{Introduction}

The data provided by studies of post-seminal development have great importance to taxonomy because they help identify essential seedling structures, understand the life and growth cycles of forest species, and interpret germination tests (MOURÃO et al., 2002; OLIVEIRA, 1993). In addition, these data can provide important information on species development, provide support for seedling production, and provide a better understanding of the process of plant establishment under natural forest conditions (GUERRA; MEDEIROS FILHO; GALLAO, 2006). Studies related to the morpho-anatomy of the fruits and seeds of forest species are relevant to understanding several phenomena associated with the behavior of these species (GARCIA; NOGUEIRA; ALQUINI, 2006).

Both the external and internal characteristics of seeds are only slightly modified by the environment, making them reliable features for identification (GUNN, 1981). Although seeds are composed mainly of the embryo, reserve tissue, and seed coat (integument), several factors contribute to the differential development of seed components, which vary among species and even within species, in terms of color, shape, and size (ABUD et al., 2010). Thus, there is a need for studies that describe biometric aspects of fruits and seeds and morphological aspects of seedlings and young plants; however, available data remain scarce because identified plant material is not always available (AMARO et al., 2006; CUNHA; FERREIRA, 2003).

The Rhamnaceae family consists of 58 genus and approximately 900 species with cosmopolitan distribution, being represented by 23 genus and 170 species in the Neotropics (HEALD, 2004). Includes trees, shrubs, lianas or herbs, unarmed or spiny. Have simple, alternate or opposite leaves, pedicellate or sessile, drupe fruit capsular or esquizocarpos, winged or not and usually seeds ellipsoid, obovate or oblong, brown, with basal embryo straight, cotyledons flat, membranous, oblong or ellipsoid (LIMA, 2011).

The species of this family are characterized by having flowers with petals to stamens opposite, being a relatively rare feature in angiosperms, occurring in the Rhamnaceae family and is associated with other families, as Vitaceae and Cornaceae. Some family members have xeromorphic adaptations such as presence or absence of leaves in low numbers, crowded leaves, shortening of the axes of branches, presence of thorns, and a shrub. The reclassification of some tribes in Rhamnaceae, based largely on molecular data and the support of some morphological characters is required (RICHARDSON et al., 2000). Many representatives of this family are used as ornamentals, in folk medicine, in cosmetics and in food animals, especially birds. The fruits are generally sweet and are already being inserted in the human diet in the form of jams and jellies (LIMA, 2006).

Rhamnidium elaeocarpum Reissek, commonly known as "cafezinho" or "cafezinho-do-cerrado" ("little coffee" or "little coffee of the savannah"), is a South American species widely distributed in Brazil that occurs in almost all states and is found in forests, especially riparian forests (LIMA, 2011). The leaves and bark of this species are commonly used in Brazil to reduce itching of the gums in children at the onset of dentition and to treat stomach pains. The leaves are opposite, simple, and hypostomatic, with tactile trichomes on the venation. The bark of the roots has scars or fissures on the outer face and fibrous fracturing on the inner face. The methanolic extract of the leaves contains significant amounts of flavonoids, alkaloids, saponins, and tannins. These data suggest that the presence of this class of substances (flavonoids, alkaloids, saponins, and tannins) may be responsible for the antiulcer activity shown by this extract because these compounds exhibit high antioxidant activity (OLIVEIRA et al., 2010). The wood is suitable for external works, such as fence posts, poles, sleepers, bridges, building construction and waterworks. The fruits are eaten 
by several species of birds, which makes it highly recommended for mixed reforestation used for restoration of degraded areas (LORENZI, 2008).

To broaden the knowledge on woody flora species of the Brazilian savannah (cerrado), this study aimed to describe the morphological and anatomical aspects of the fruits, seeds and seedlings of Rhamnidium elaeocarpum Reissek.

\section{Materials and Methods}

\section{Collection and processing}

The fruit were collected at the Padre Galileu Farm in the municipality of Jaupaci, GO, Brazil. Five plants were selected at a minimum distance of $100 \mathrm{~m}$ apart, taking into consideration the fruit color to determine the ripening point. After collection, the fruits were sent to the Laboratory of Seed Analysis in the Department of Agriculture of the Federal University of Lavras (Universidade Federal de Lavras - UFLA), where the tests were performed.

The studies on seed anatomy were performed at the Laboratory of Plant Anatomy of the Goiano Federal Institute (Instituto Federal Goiano IFGoiano) - Rio Verde Campus, GO, Brazil. The processing consisted of the maceration of ripe fruits in sieves (5-mm pore size) under running water to separate the seeds from the waste. The seeds were dried at room temperature on paper towels until the excess water was removed and then packed in plastic bags and stored in a cold room $\left(10^{\circ} \mathrm{C}\right.$ and $40-50 \%$ humidity) until the assays were performed. The level of humidity in the seeds was determined using the incubator method at $105 \pm 3^{\circ} \mathrm{C}$ for 24 hours (BRASIL, 2009), with four sub-samples of ten seeds. The results were calculated based on the weight of the moist seeds and expressed as a percentage.

\section{Fruit morphology and biometrics}

The following aspects were considered in the morphological study of the fruit: type, color, dimensions, texture and consistency of the pericarp, dehiscence, and the number of seeds per fruit, as recommended by Damião-Filho (1993), Barroso et al. (1999) and Damião-Filho and Môro (2005). The mean, maximum, and minimum length and width were measured using a Digimed digital caliper (accurate to $0.01 \mathrm{~mm}$ ) on 50 fruit randomly selected from the study sample.

\section{Morphological aspects of the seeds}

The length, width, and thickness of the seeds were measured using a digital caliper (accurate to $0.01 \mathrm{~mm}$ ) on a sample of 100 randomly selected seeds. Length was considered as the distance between the basal and apical ends of the seed. The width and thickness were measured in the middle part of the seed. The arithmetic mean, standard deviation, and coefficient of variation $(\mathrm{CV})$ were calculated for each of the variables. For seeds, the external aspects observed and described included the color, texture and consistency of the integument; the shape and edge of the seeds; and the position of the hilum, micropyle, and other structures present. The internal features described included the presence or absence of endosperm; the position and shape of the embryonic axis; and the texture, color, and shape of the cotyledons. To facilitate the study of internal morphology, the seeds were hydrated, cut crosssectionally and longitudinally with steel blades, and then observed in greater detail using a table magnifying glass and a stereoscopic microscope. The inner and outer surfaces were documented using a camera. The methods and terms used were based on the studies of Vidal and Vidal (2007), Oliveira (1993), Damião-Filho (1993), Barroso et al. (1999), and Damião-Filho and Môro (2005). X-ray images of internal structures were obtained as an auxiliary tool in morphological studies of the seeds. The seeds were placed in clear acrylic plates on doublesided tape and irradiated on an HP Faxitron model $43855^{\text {a }} \mathrm{X}$-ray machine to obtain digital images of the internal seed structures. 


\section{Anatomical characterization of the seeds}

Mature seeds were anatomically evaluated in cross-sections. For the preparation of anatomical sections, the material was fixed in $\mathrm{FAA}_{70 \%}$ (formalin, acetic acid and ethyl alcohol), dehydrated in a graded ethanol-butanol series, and embedded in historesin at $58^{\circ} \mathrm{C}$. Histological sections $(15 \mu \mathrm{m})$ were prepared using a microtome, stained in $0.05 \%$ toluidine blue - polychromatic stain (O'BRIEN; FEDER; McCULLY, 1964), and mounted on permanent slides with synthetic historesin. The results are illustrated by photomicrographs obtained with a Leica DM500 photomicroscope, adding appropriate scale bars for the optical conditions. The anatomy of seeds was described according Appezzato-daGlória and Carmello-Guerreiro (2006). Some sections were prepared for histochemical tests to identify the presence of certain substances. Vanillin hydrochloride (MACE; HOWELL, 1974; KRAUS; ARDUIM, 1997) was used to verify the presence of phenolic compounds (tannins), and Sudan IV (JOHANSEN, 1940) was used to visualize the location of lipid substances (vegetable oil).

\section{Germination}

The seeds were placed on a paper substrate to germinate, kept moist using distilled water to 2.5 times the dry weight, and held in a dark incubation chamber at $25^{\circ} \mathrm{C}$. Four replicates of 50 seeds each were used. Germination was monitored daily for 10 days. Germination was considered the period between seed intumescence and hypocotyl elongation, before the first foliage leaf is completely formed. The germination type and the shape, color, and consistency of the root and epicotyl were analyzed. The basic structures of each stage of germination were measured using calipers and documented using a camera. The method and terminology used were in accordance with Vidal and Vidal (2007) and Damião-Filho and Môro (2005).

\section{Morphological aspects of the seedlings}

To monitor the development of seedlings, 200 seeds were sown on plastic trays measuring $40 \mathrm{x}$ $30 \times 8 \mathrm{~cm}$ containing a mixture of subsoil and sand at a 3:1 ratio as a substrate. The seeds were sown $3 \mathrm{~cm}$ deep, and the substrate was wetted to $70 \%$ of its field capacity and irrigated when necessary. The trays were kept in a growth chamber at $25^{\circ} \mathrm{C}$ for 25 days. A seedling was considered to be the developmental stage at which the plants had welldeveloped primary and secondary roots, hypocotyl, epicotyl, and protophylls (the first pair of leaves that emerge after the opening of the cotyledons).

\section{Results and Discussion}

\section{Morphological aspects of the fruits}

The fruit had a mean length of $11.0 \mathrm{~mm}$ (ranging from 9.4 to $12.3 \mathrm{~mm}$ ) and a mean width of $8.9 \mathrm{~mm}$ (ranging from 4.4 to $10.7 \mathrm{~mm}$ ), as shown in Table 1.

Table 1. The length, width, and thickness of Rhamnidium elaeocarpum Reissek fruits and seeds.

\begin{tabular}{ccccccccccc}
\hline Dimension & \multicolumn{2}{c}{ Mean } & \multicolumn{2}{c}{ Maximum } & \multicolumn{2}{c}{ Minimum } & \multicolumn{2}{c}{ Standard deviation } & \multicolumn{2}{c}{ CV (\%) } \\
\cline { 2 - 11 }$(\mathbf{m m})$ & fruits & seeds & fruits & seeds & fruits & seeds & fruits & seeds & fruits & seeds \\
\hline Length & 11.06 & 7.67 & 12.35 & 9.55 & 9.42 & 6.45 & 0.61 & 0.60 & 5.50 & 7.88 \\
Width & 8.97 & 4.34 & 10.77 & 5.03 & 4.43 & 3.49 & 0.91 & 0.29 & 10.14 & 6.93 \\
Thickness & -- & 3.49 & -- & 4.84 & -- & 2.88 & -- & 0.33 & -- & 9.41 \\
\hline
\end{tabular}

Source: Elaboration of the authors. 
The fruit is a simple, fleshy, and indehiscent berry, with a purple epicarp when ripe, a smooth and shiny surface, and an acute apex and base (Figure 1 A to D), and it contains only one seed per fruit.
The fruits of Juazeiro (Zizyphus joazeiro Mart., Family - Rhamnaceae), are the type globose drupe with hard, woody, indehiscent, fleshy endocarp and can be monospermic or contain two seeds (SILVA; MATOS, 1998).

Figure 1. Fruits of Rhamnidium elaeocarpum Reissek. A - branches with green and ripe fruits; B - fruits in different ripening stages; $\mathrm{C}$ - ripe fruits; D - fruit/longitudinal section. (en - endocarp; ep - epicarp; me - mesocarp). Scale bar $=1.0 \mathrm{~cm}$.

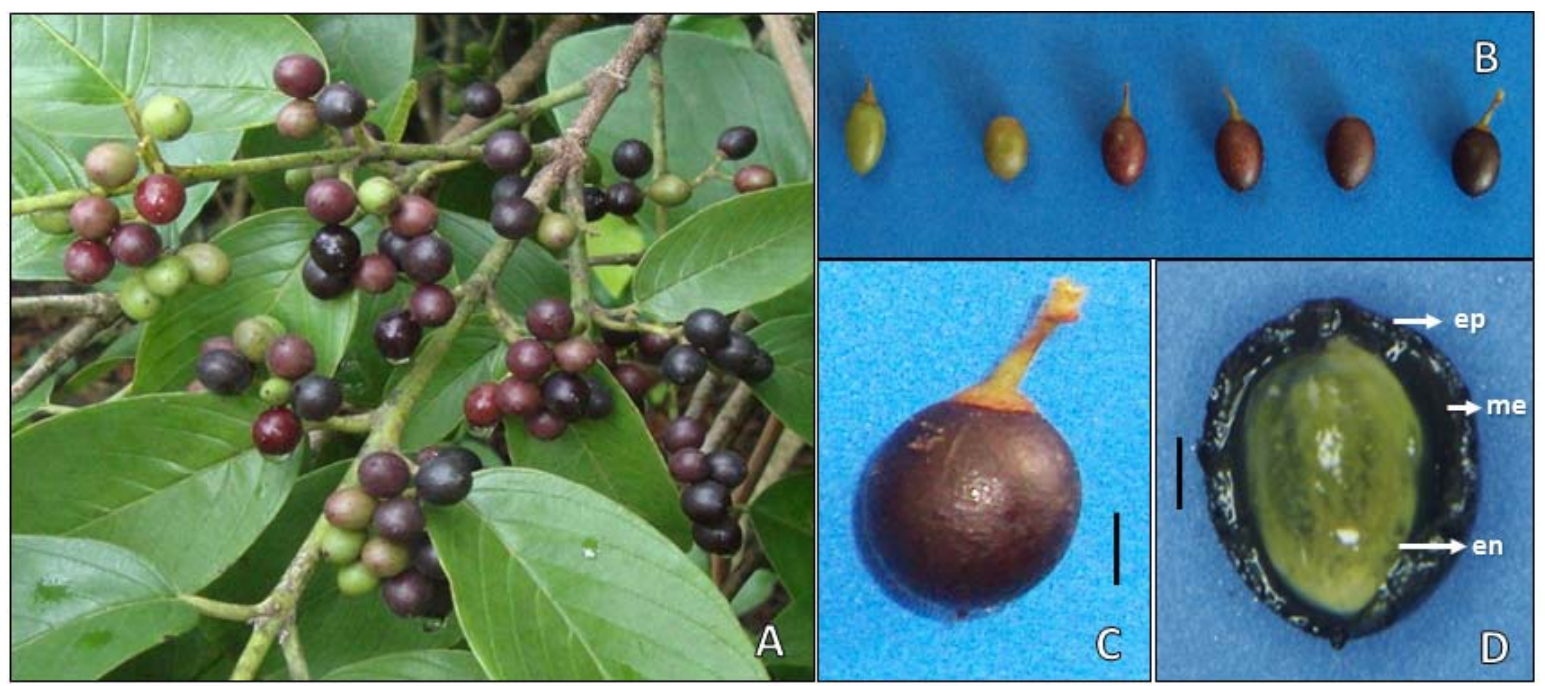

Source: Elaboration of the authors.

\section{Morphological aspects of the seeds}

The seeds had an initial humidity of $37 \%$ w.b. and a mean length of $7.6 \mathrm{~mm}$ (ranging from 6.4 to $9.5 \mathrm{~mm}$ ), a mean width of $4.3 \mathrm{~mm}$ (ranging from 3.4 to $5.0 \mathrm{~mm}$ ), and a mean thickness of $3.4 \mathrm{~mm}$ (ranging from 2.8 to $4.8 \mathrm{~mm}$ ), as shown in Table 1. The seeds of Juazeiro (Zizyphus joazeiro Mart., Family - Rhamnaceae), feature, 0,7-1,0 cm long by 0,5-0,7 cm wide (SILVA; MATOS, 1998).

The morphometric differences may affect the adaptive value of the trees and the regeneration of the population. However, the variation among individuals in a population allows for the selection and improvement of a given character, making individual variation one of the most important sources of variability and assisting in the study of dispersion and dispersal agents (SANTOS et al., 2009).
The seed is exalbuminous with an elliptical shape, thinned apex and base, thick tegument, cream color, and rough surface; the hilum is basal and slightly conspicuous, and the micropyle is located at the apex of the seed (Figure 2 A to C). The cotyledons are membranous and pale green and occupy small portion of the internal structure of the seed, with a thick, yellowish root-hypocotyl axis, inconspicuous plumule (Figure $2 \mathrm{D}$ to F). The seeds are surrounded by a transparent mucilage, difficult to separate. According to Lima (2006), representatives of the Rhamnaceae family generally have ellipsoid seeds that are ovate or oblong, brown, and have a straight basal embryo and flat, membranaceous, oblong, or ellipsoid cotyledons. 
Figure 2. Seeds of Rhamnidium elaeocarpum Reissek; A - whole seeds; B - seed/cross-section; C, D - seed/ longitudinal section; E, F - radiographs of seeds. (c - cotyledon; rha - hypocotyl radicular axis; ed - endosperm; h hilum; $\mathrm{mi}$ - micropyle; $\mathrm{t}$ - integument). Scale $\mathrm{bar}=1.0 \mathrm{~cm}$.

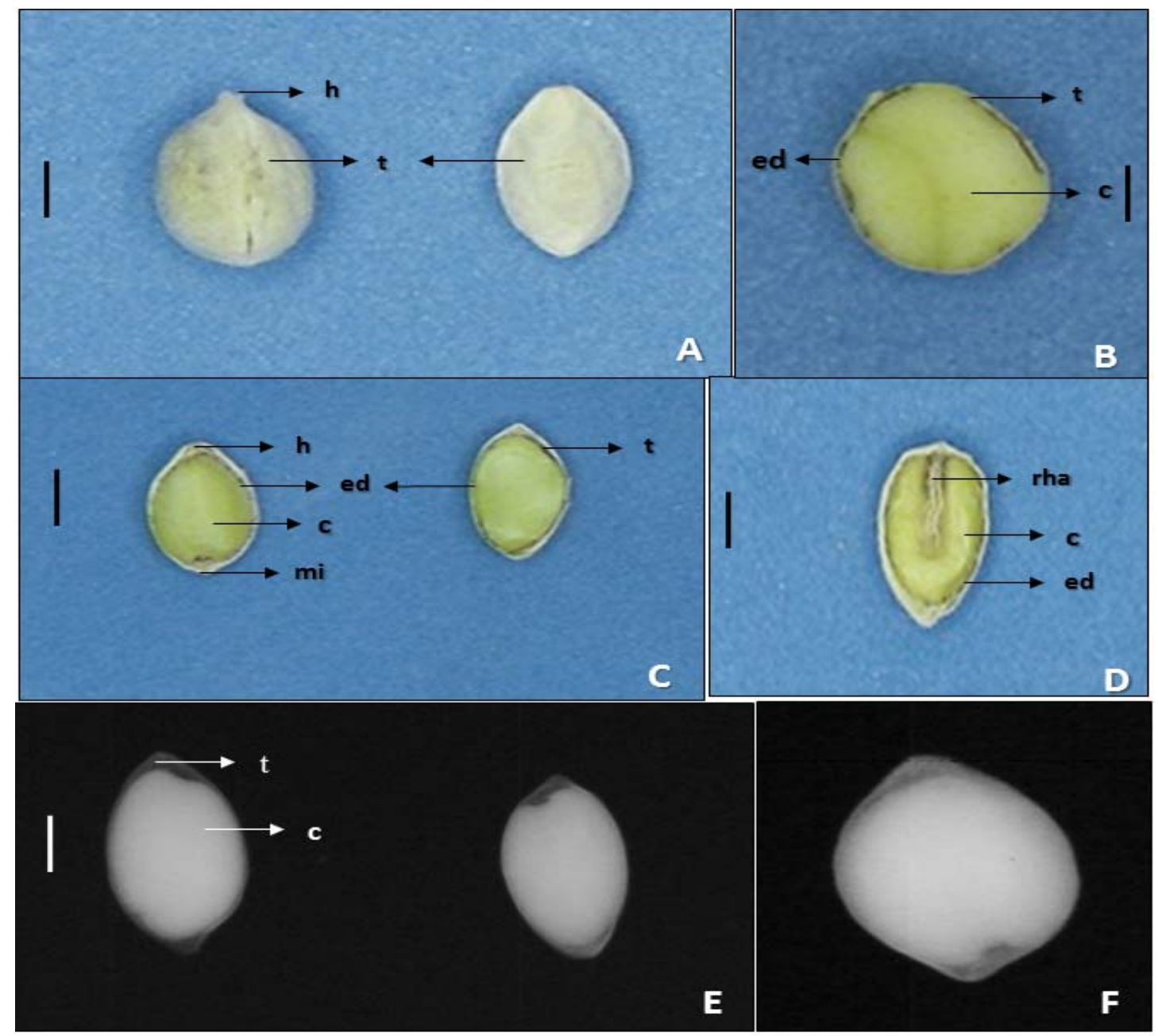

Source: Elaboration of the authors.

The seeds of Juazeiro (Zizyphus joazeiro Mart., Family - Rhamnaceae), are stenospermics, ovate or elliptic, axial embryo straight, flat and invaginated; cotyledons foliaceous with $0,5-0,8 \mathrm{~cm}$ long by $0,4-$ $0,7 \mathrm{~cm}$ wide, beige, oblong or elliptical coloration of apex and rounded base, shaft cylindrical hypocotylradicle, small and beige coloring; inconspicuous plumule (SILVA; MATOS, 1998).

\section{Anatomical characterization of the seed}

The tegument is thin and consists of several cell layers (Figure $3 \mathrm{~A}$ ). The epidermis is made up of thin, elongated cells forming the tegument. The sclerenchyma is visible below the epidermis and can be divided into two strata: the first consisting of elongated sclereids and the second of rounded sclereids. Both sclereid layers form the sclerenchyma, which stiffens the seed coat. Below the sclerenchyma, there are rectangular calcium oxalate crystals. Histochemical analysis with vanillin hydrochloride revealed the presence of tannin cells in the outermost layer of the seed, which may be related to protection against attack by predators or microorganisms or increasing the hardness of the tegument (Figure $3 \mathrm{E}$ ). 
Figure 3. Cross-sections of Rhamnidium elaeocarpum Reissek seeds. A - overview of the integument; B - overview of the endosperm; $\mathrm{C}$ - starchy endosperm cells, highlighting a cell with drusen; D - endosperm, with prominent oil ducts; $\mathrm{E}$ - the tannin content of the integument; $\mathrm{F}$ - lipid-rich cells. (Ag - fatty acids; $\mathrm{Ca}$ - cells with starch content; $\mathrm{Cr}$ - rectangular crystals; D - drusen; Do - oil ducts; Ep - epidermis; Es - sclerenchyma; Tn - tannin content on the integument).
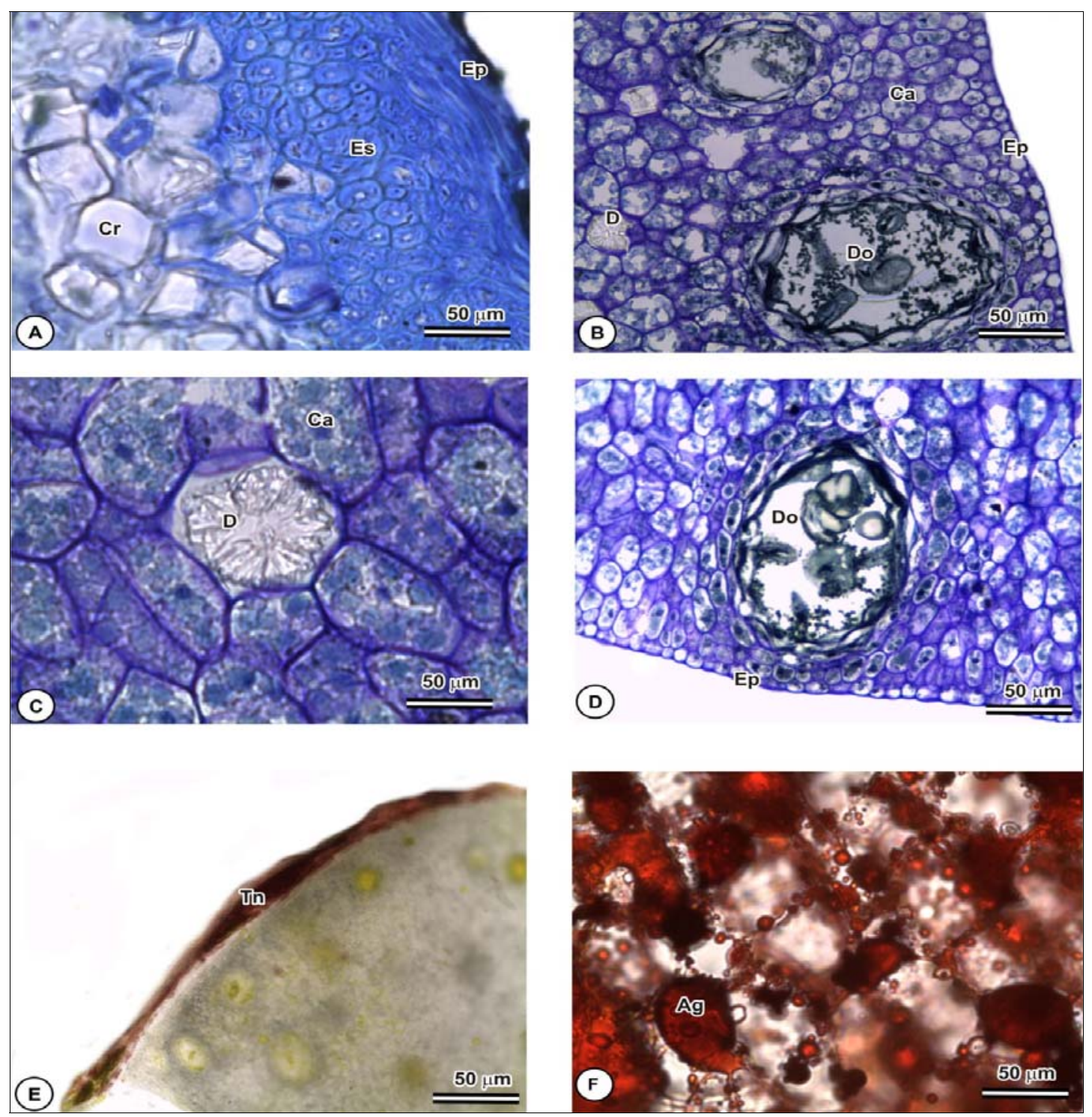

Source: Elaboration of the authors. 
The endosperm has a uniseriate epidermis, and within the inner layer, there are cells with large numbers of starch granules, calcium oxalate crystals grouped to form drusen, and oil ducts throughout the endosperm (Figure $3 \mathrm{~B}$ to $\mathrm{D}$ ). According to Felippi et al. (2010) the role of calcium oxalate crystals in the embryo remains unknown. However, differences among the results of several studies suggest that control of the crystallization is influenced by external factors (such as the calcium concentration in the soil). Lacchia and CarmelloGuerreiro (2009) observed that epithelial cells of the fruit of Anacardium humile (Anacardiaceae) also had a large number of rounded plastids with a circular membrane system, which are involved in the synthesis of lipophilic substances. Tannincontaining cells were not detected with a vanillin hydrochloride test; however, the Sudan IV test revealed lipid-rich cells in the endosperm (Figure 3 F). Silva and Paoli (2006) also reported the presence of protein reserves and lipid content in the endosperm of Dictyoloma vandellianum seeds detected with the Sudan IV test.

\section{Morphological aspects of germination and seedlings}

The germination is hypogeal cryptocotylar and unipolar, with the seed keeping the cotyledons covered by the seminal integument throughout seedling development (Figure 4). Initially there is hydration of the seed, which intumesces and increases in volume; next, the radicle emerges between the $2^{\text {nd }}$ and $3^{\text {rd }}$ day (Figure $4-\mathrm{A}$ ). The primary cylindrical root initially has a whitish color and becomes darker during development (Figure $4-\mathrm{B}, \mathrm{C}$ and D). A slight dilatation of the radicle apex marks the beginning of the root cap, which is cylindrical, elongated and ends in a sharp tip (Figure $4-\mathrm{D}$ to $\mathrm{F}$ ), of yellowish color. The germination process is fast and uniform, reaching $95 \%$ of germination four days after sowing.

The first protophylls are observed between the $6^{\text {th }}$ and $8^{\text {th }}$ days after germination (Figure $5 \mathrm{~A}$ to $\mathrm{C}$ ). The seedling is fully formed by the $15^{\text {th }}$ day, with a taproot 4 to $6 \mathrm{~cm}$ in length, a well-defined root cap, and thin and yellowish secondary roots. The roots have simple, translucent hairs that are only visible under a stereomicroscope (Figure $5 \mathrm{D}$ and $\mathrm{E}$ ). There is a short, greenish hypocotyl and a cylindrical, shiny, light-green epicotyl, with a mean length of $3.5 \mathrm{~cm}$ (Figure $5 \mathrm{~A}$ to E). The protophylls are simple, opposite, petiolate, and elliptical and have pinnate venation (Figure $5 \mathrm{~F}$ ). The seedlings exhibit rapid epicotyl development and accelerated formation and expansion of new leaves. This species exhibits polyembryony, in some cases developing more than one seedling per seed (Figure $5 \mathrm{~B}$ ).

The germination of juazeiro (Zizyphus joazeiro Mart.), are epigeal and seedlings fanerocotilar. On the fifteenth day the seedling presented is formed, characterized by presenting axial white tortuous flexuosa and fine roots, with 6,8 to $8,5 \mathrm{~cm}$ long, with short and thin secondary roots (SILVA; MATOS, 1998). 
Figure 4. Germination aspects of Rhamnidium elaeocarpum Reissek; $\mathrm{A}$ - intumescence of the seed and root protrusion; B; C; D - Elongation of the primary root and development of secondary roots; E - Appearance of the epicotyl; F Expansion of the epicotyl. (c - cotyledon; rc - root cap; ep - epicotyl; hp - hypocotyl; $h$ - absorbent hairs; $p r$ primary root; $\mathrm{sr}$ - secondary root; $\mathrm{s}$ - seed; $\mathrm{t}$ - integument). Scale bars: $1.0 \mathrm{~cm}$ for $\mathrm{A}$ and $\mathrm{B} ; 2.0 \mathrm{~cm}$ for $\mathrm{E}$ and $\mathrm{F}$.
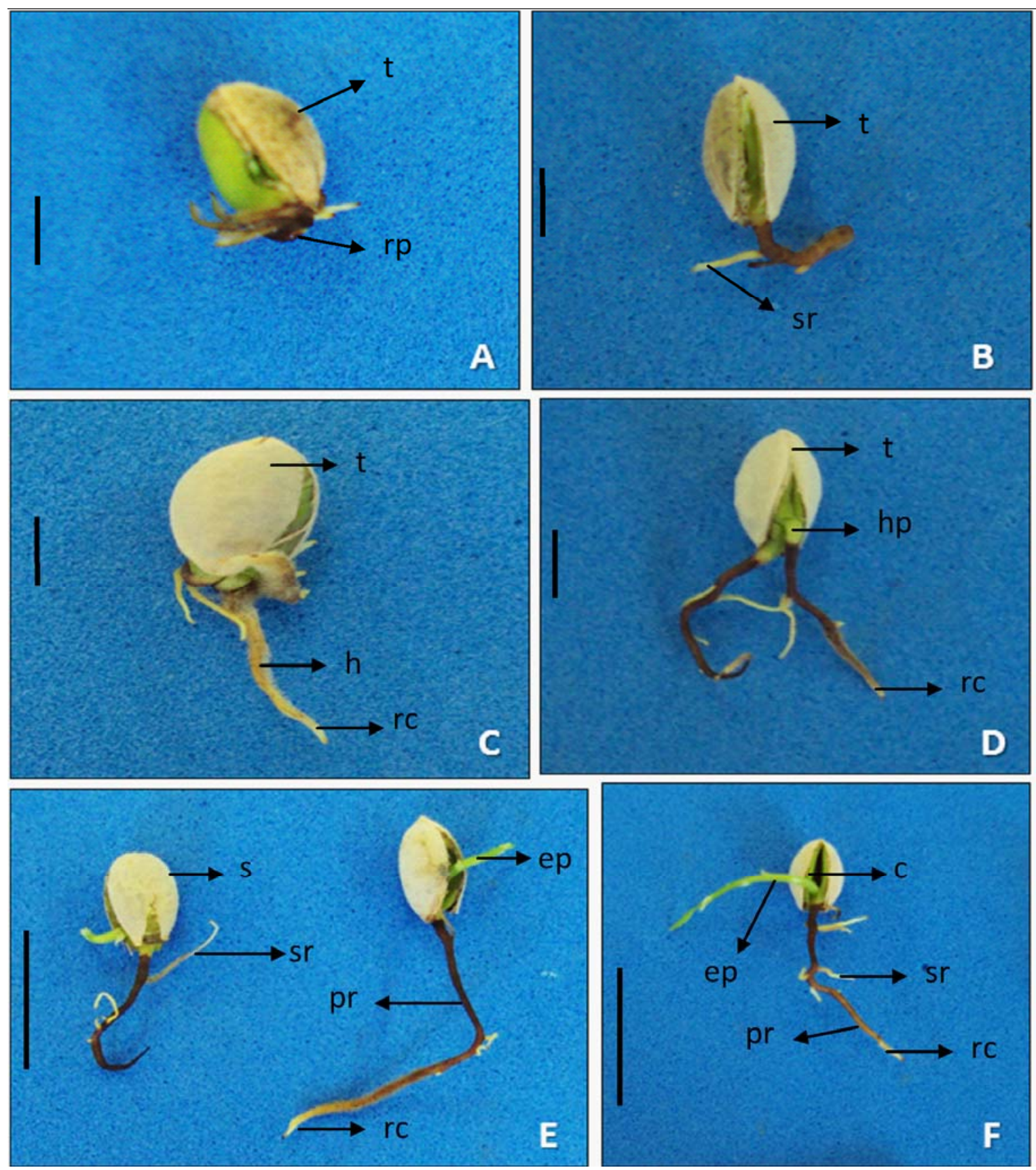

Source: Elaboration of the authors. 
Figure 5. Seedling development in Rhamnidium elaeocarpum Reissek; A - the appearance of $1^{\text {st }}$-order protophylls; $\mathrm{B}$ to $\mathrm{D}$ - the development of secondary and tertiary roots; $\mathrm{E}$ - the expansion of protophylls; $\mathrm{F}$ - a fully formed young plant. (ca - stalk; cj - young stalk; ep - epicotyl; f - leaf; hp - hypocotyl; pro - protophyl; ps - secondary seedling; $\mathrm{rp}$ - primary root; $\mathrm{rs}$ - secondary root; $\mathrm{rt}$ - tertiary root). Scale bars: $3.0 \mathrm{~cm}$ for A; $5.0 \mathrm{~cm}$ for $\mathrm{E}$ and $\mathrm{F}$.

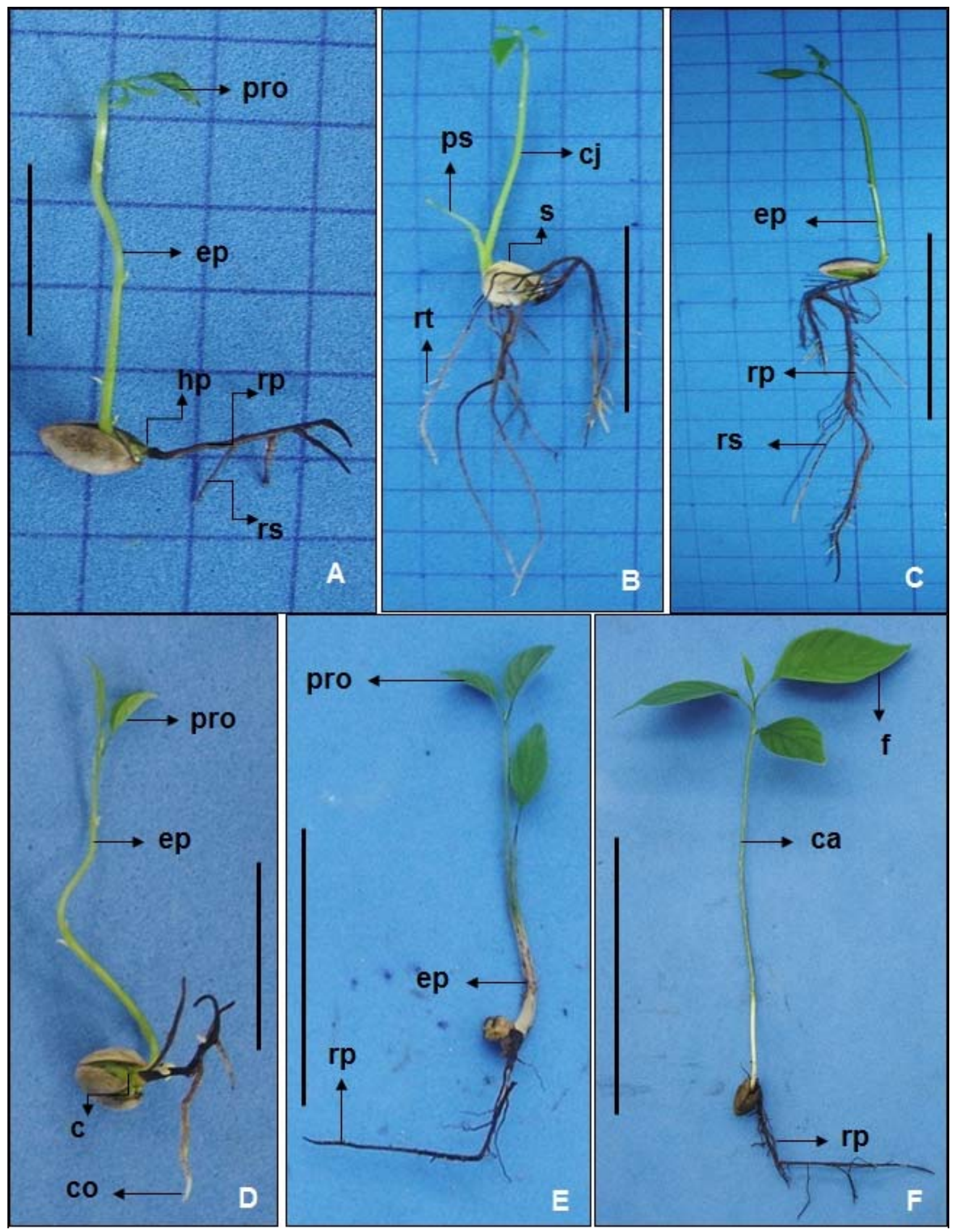

Source: Elaboration of the authors. 


\section{Conclusions}

The morphological aspects of the seeds, germination, and seedlings of Rhamnidium elaeocarpum Reissek are homogenous in all phases.

The fruit is simple, fleshy, indehiscent, and berry monospermic. The seed is exalbuminous and cream colored, with a thin and rough integument, the presence of tannin content, and an endosperm rich in starch, calcium oxalate crystals, and lipid content. Germination is hypogeal, and the seedling is cryptocotyledonary.

\section{References}

ABUD, H. F.; GONCALVES, N. R.; REIS, R. G. E.; GALLÃO, M. I.; INNECCO, R. Morfologia de sementes e plântulas de cártamos. Revista Ciência Agronômica, Fortaleza, v. 41, n. 2, p. 259-265, 2010.

AMARO, M. S.; MEDEIROS FILHO, S. M.; GUIMARÃES, R. M.; TEÓFILO, E. M. Morfologia de frutos, sementes e de plântulas de Janaguba (Himatanthus drasticus (MART.) PLUMEL.- (Apocynaceae). Revista Brasileira de Sementes, Londrina, v. 28, n. 1, p. 63-71, 2006.

APPEZZATO-DA-GLÓRIA, B.; CARMELLOGUERREIRO, S. M. Anatomia vegetal. 2. ed. Viçosa: UFV, 2006. 438 p.

BARROSO, G. M.; MORIM, M. P.; PEIXOTO, A. L.; ICHASO, C. L. F. Frutos e sementes: morfologia aplicada à sistemática de dicotiledôneas. Viçosa, MG: Universidade Federal de Viçosa, 1999. 443 p.

BRASIL. Ministério da Agricultura, Pecuária e Abastecimento. Regras para análise de sementes. Ministério da Agricultura, Pecuária e Abastecimento. Secretaria de Defesa Agropecuária. Brasília: SNDA/ DNDV/CLAV, 2009. 398 p.

CUNHA, M. C. L.; FERREIRA, R. A. Aspectos morfológicos da semente e do desenvolvimento da planta jovem de Amburana cearensis (Arr. Cam.) A.C. Smith - cumaru - Leguminosae- Papilionoideae. Revista Brasileira de Sementes, Londrina, v. 25, n. 2, p. 89-96, 2003.

DAMIÃO-FILHO, C. F. Morfologia e anatomia de sementes. Jaboticabal: FCAV/UNESP, 1993. 145 p. (Apostila da disciplina do Curso Pós-graduação Morfologia e Anatomia de Sementes).
DAMIÃO-FILHO, C. F.; MÔRO, F. V. Morfologia vegetal. 2. ed. Jaboticabal: FUNEP, 2005. 172 p.

FELIPPI, M.; GROSSI, F.; NOGUEIRA, A. C.; MOCO, M. C. C. Desenvolvimento da semente de Chrysophyllum gonocarpum (Mart. \& Eichl.) Engl. (Sapotaceae). Revista Brasileira de Sementes, Londrina, v.32, n. 1, p. 92-100, 2010.

GARCIA, L. C.; NOGUEIRA, A. C.; ALQUINI, Y. Aspectos morfo-anatômicos de sementes de Podocarpus lambertii Klotz. e Podocarpus sellowii Klotz. - Podocarpaceae. Revista Brasileira de Sementes, Londrina, v. 28, n. 3, p. 129-134, 2006.

GUERRA, M. E. C.; MEDEIROS FILHO, S.; GALLAO, M. I. Morfologia de sementes, de plântulas e da germinação de Copaifera langsdorfii Desf. (Leguminosae - Caesalpinioideae). Cerne, Lavras, v. 12, n. 4, p. 322328, 2006.

GUNN, C. R. Seed topography in the Fabaceae. Seed Science and Technology, Zurique, v. 9, n. 3, p. 737-757, 1981.

HEALD, S. V. Rhamnaceae. In: SMITH, N.; MORI, S. A.; HENDERSON, A.; STEVENSON, D. W.; HEALD, S .V. (Ed.). Flowering plants of the neotropics. New Jersey: Princeton University Press. 2004. p. 323-324.

JOHANSEN, D. A. Plant microtechnique. New york: McGraw-Hill Book Co. Inc., 1940. 423 p.

KRAUS, J. E.; ARDUIN, M. Manual básico de métodos em morfologia vegetal. Rio de Janeiro: EDUR, 1997. 198 p.

LACCHIA, A. P. S.; CARMELlO-GUERREIRO, S. M. Aspectos ultra-estruturais dos canais secretores em órgãos vegetativos e reprodutivos de Anacardiaceae. Acta Botanica Brasilica, Belo Horizonte, v. 23, n. 2, p. 376-388, 2009.

LIMA, R. B. Flora da reserva Ducke, Amazonas, Brasil: Rhamnaceae. Rodriguésia, Rio de Janeiro, v. 57, n. 2, 247-249, 2006.

Flora da Serra do Cipó, Minas Gerais: Rhamnaceae. Boletim de Botânica, Departamento de Botânica, São Paulo, v. 29, n. 1, p. 47-55, 2011.

LORENZI, H. Árvores brasileiras: manual de identificação e cultivo de plantas arbóreas do Brasil. 5. ed. Nova Odessa: Instituto Plantarum, 2008. v. 1, 384 p.

MACE, M. E.; HOWELL, C. R. Histochemistry and identification of condensed tannin precursor in roots of cotton seedlings. Canadian Journal of Botany, Ottawa, v. 52, n. 11, p. 2423-2426, 1974. 
MOURÃO, K. S. M.; DIAS-PINTO, D.; SOUZA, L. A.; MOSCHETA, I. S. Morfo-anatomia da plântula e do tirodendro de Trichilia catiguá A. Juss., T. elegans A. Juss. e T. pallida Sw. (Meliaceae). Acta Scientiarum Biological Sciences, Maringá, v. 24, n. 2, p. 601-610, 2002.

O'BRIEN, T. P.; FEDER, N.; McCULLY, M. E. Polychromatic staining of plant cell walls by toluidine blue O. Protoplasma, Heidelberg, v. 59, n. 2, p. 368-373, 1964.

OLIVEIRA, E. C. Morfologia e análise de plântulas florestais. In: AGUIAR; I. B.; PIÑA-RODRIGUES, F. C. M.; FIGLIOLIA, M. B. (Ed.) Sementes florestais tropicais. Brasília: ABRATES, 1993. p. 175-214.

OLIVEIRA, T. B.; SOARES, R. L.; TRESVESOL, L. M. F.; BRANQUINHO, D. S. P.; BARA, M. T. F.; FIUZA, T. S.; REZENDE, M. H.; PAULA, J. R. Caracterização das Folhas e Cascas da Rhamnidium elaeocarpum Reissek. Latin American Journal of Pharmacy, Buenos Aires, v. 29, n. 4, p. 534-541, 2010.
RICHARDSON, J. E.; FAY, M. F.; CRONK, Q. C.; BOWMAN, D.; CHASE, M. W. A phylogenetic analysis of Rhamnaceae using RBCL and TRNL-F plastid DNA sequences. American Journal of Botany, St. Louis, v.87, n. 9, p. 1309-1324, 2000.

SANTOS, F. S.; PAULA, R. C.; SABONARO, D. Z.; VALADARES, J. Biometria e qualidade fisiológica de sementes de diferentes matrizes de Tabebuia chrysotricha (Mart. Ex A. DC.) Standl. Scientia Forestalis, Piracicaba, v. 37, n. 82, p. 163-173, 2009.

SILVA, L. L.; PAOLI, A. A. S. Morfologia e anatomia da semente de Dictyoloma vandellianum Adr. Juss. (Rutaceae). Revista Brasileira de Sementes, Londrina, v. 28, n. 3, p. 116-120, 2006.

SILVA, L. M. M.; MATOS, V. P. Morfologia de frutos, sementes e plântulas de catingueira (I Tul.Caesalpinaceae) e de juazeiro (Zizyphus joazeiro Mart.- Rhamnanaceae). Revista Brasileira de Sementes, Londrina, v. 20, n. 2, p. 25-31, 1998.

VIDAL, W. N.; VIDAL, M. R. R. Botânica organografia: quadros sinóticos ilustrados de fanerógamos. Viçosa: UFV, 2007. 124 p. 